\title{
Evaluation of unprotected steel beam temperature during fire using CFD simulation
}

\author{
Paulína Magdolenová ${ }^{1, *}$ \\ ${ }^{1}$ University of Zilina, Faculty of Security Engineering, Univerzitná 8215/1, 01026 Žilina, Slovakia
}

\begin{abstract}
Fire resistance of building construction is essential part of the design process. Thermal loading of loadbearing elements can be obtained by using simplified standard fire curve or advanced numerical fire model. The paper shows the process of numerical fire modelling in unprotected steel structure carpark using the Computational Fluid Dynamics (CFD) method. In Fire Dynamics Simulator (FDS) software, three scenarios are created to represent open, semi-open and closed carpark building. The resultant HEB500 beam temperatures are compared with standard evaluated temperatures.
\end{abstract}

\section{Introduction}

Extraordinary load events, such as fire or blast, cause adverse effects on building construction as shown by previous studies [1-4]. Therefore, fire resistance design of loadbearing construction elements is essential part of general building design and analysis according to currently valid laws and regulations. In Slovakia, since 2010, a set of European technical standards for structural design called Eurocodes has been used and is uniform within the whole European Union. The standard approach of construction design under thermal loading by fire is addressed in the standard STN EN 191-1-2 [5] which is part of the Eurocode 1. The subject of this standard are thermal and mechanical loads of fire-stressed structures, their general principles and application rules.

Generally, the standard [5] provides two options of thermal load evaluation, by nominal fire curve of by numerical model. Thereafter, the chosen approach affects the follow-up structural analysis which can be carried out by basic or advanced numerical models.

Civil engineers mostly apply the basic approach by using the standard fire curve (known as ISO 834 [6]) and normalized structural fire resistance evaluation, which usually provides sufficient results. However, the standard fire curve interprets the temperature-time development of an enclosure fire in a very simplified way. The standard fire curve does not take into account, fire material characteristic of designed fire load, its spatial layout and volume, and boundary conditions of the designed space. Moreover, the standard fire curve neglects the initial phase of fire growth as well as the last phase of afterburning [7]. In reality, such fire behaviour does not occur, as after the consumption of the combustible material (fire load) the fire burns out and / or is shifted. Therefore, the number of cases that confirm the assumption of dissonance between the standard fire curve and enclosure fire in

* Corresponding author: paulina.magdolenova@fbi.uniza.sk 
real conditions is rising [8]. For these reasons, there are specific cases where the advanced design approach involving a numerical fire model is appropriate to apply.

One of such cases is the design of an unprotected steel construction which has been applied on various multi-storey car parks projects within the EU in recent years. That is caused by reduced construction fire resistance requirements for open carparks defined by national annex of the standard [5]. Consequently, the required fire resistance time of such buildings varies from 0 to 90 minutes within the EU countries where the reduction is defined $[9,10]$. However, some countries, Slovakia included, does not have any specific requirements for open carparks defined by national standards. This brings up the possibility of the advanced fire design approach to be applied in order to design the open carpark unprotected steel construction to optimize its price [11]. Proper numerical fire model is the key element of such approach and its realization requires multiple engineering skills and techniques, which leads to the motivation of this paper.

The aim of the paper is to create the advanced numerical fire model in the carpark building using the Computational Fluid Dynamics (CFD) method. Overall, three scenarios are created as open, semi-open and closed carpark in order to testify the simulation ability to incorporate different boundary conditions. Models are created in software Fire Dynamics Simulator (FDS) to obtain structural element temperatures during fire. Obtained data are compared to structural temperatures evaluated by simplified normalized approach [12] using the standard fire curve. The simulation results represent the input data for a follow-up advanced structural model (generally a Finite Element Method model) to determine the element fire resistance time.

\section{Materials and methods}

The CFD fire model currently represents the most advanced form of the fire model, which can be used according to the standard [5] to describe the enclosure fire development in the process of fire resistance design. It is characterized as a numerical fluid dynamic model providing the overall temperature evolution in the modelled section as a function of time and space. It is a solution of calculations needed to simulate the interaction of liquids and gases with surfaces defined by boundary conditions. To study the fluid motion/flow, the Euler method is applied in CFD, by which we observe changes in quantities characterizing the properties of moving/flowing fluid at a certain fixed point of space filled with fluid and at the same time we monitor the velocity of all fluid particles at a certain moment. The basic equations for CFD are the continuity equation for one-phase three-dimensional unsteady flow and the Navier-Stokes equation for the momentum balance.

The FDS is a widely used software for enclosure fire models using the CFD method and is developed by National Institute of Standards and Technology (NIST). This software solves numerically a form of the Navier-Stokes equations appropriate for low-speed, thermally driven flow, with an emphasis on smoke and heat transport from fires [13]. The created scenarios are modelled according to software user guide [14] rules and instructions.

The modelled geometry conforms with the dimensions of a five-store carpark building that was designed with 256 parking lots, 64 for each storey, according to all national requirements. The floor area of one storey is $56 \times 33 \mathrm{~m}$, see Fig. 1, and the ceiling height is $3 \mathrm{~m}$. According to STN 92 0201-2, the fire resistance of loadbearing elements of this building should be minimum 30 minutes (R30).

The created fire scenarios are modelled in order to obtain the surface temperatures of chosen unprotected steel beam. The chosen element is $12 \mathrm{~m}$ long and is designed as a HEB500 cross-section of a S355 steel grade according to national Eurocode design 
requirements for standard room temperature $20^{\circ} \mathrm{C}$. The position of the chosen beam is shown in Fig. 1 with red colour.

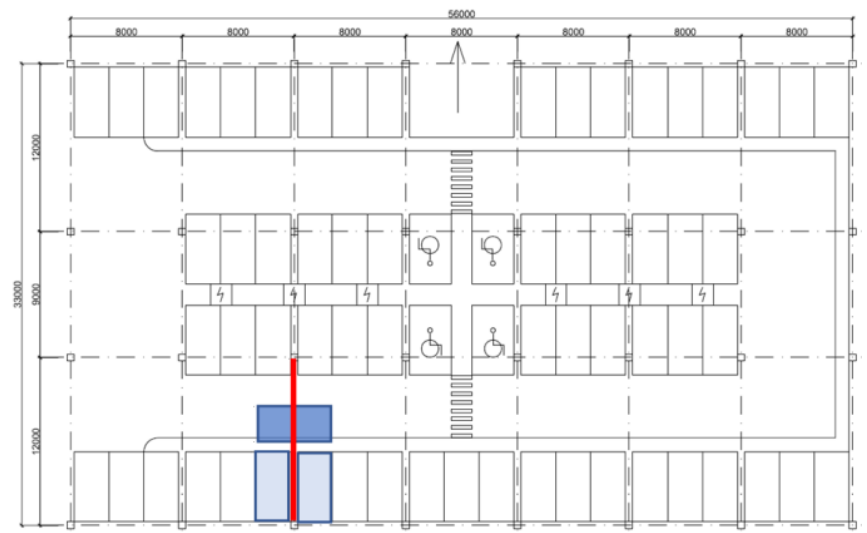

Fig. 1. Floor plan of designed carpark with burning cars and analysed beam position.

In Fig. 1, burning cars of created fire scenarios are highlighted with blue colour. This layout of burning cars was chosen to represent the fire load that would contribute to obtaining highest temperatures of the chosen beam. The fire scenario is based on previously studied carpark fire assumptions that the fire spread between two gasoline cars with average parking distance $(70 \mathrm{~cm})$ is 12 minutes and at most 3-4 vehicles on fire at the same time should be considered $[9,10,15]$. This leads to the fire scenario where the first burning car is placed under the middle of the chosen beam where the element bending moment has the highest value (dark blue colour in Fig. 1). The car fire starts in simulation time $t=0$ seconds. The position of this car enables to spread the fire to two adjacent cars at the same time. According to the mentioned assumptions, these two cars start burning after 12 minutes at the time of simulation $t=720$ seconds and their position is shown with light blue colour in Fig. 1.

Before modelling the scenario, single car fire model was created in order to carry out the mesh sensitivity analysis. The geometry of the modelled car (Fig. 2 left) is based on combination of a simple car FDS model by Markert and Guiliani [9] and an advanced model by Heinisuo and Partanen [10]. The car fire heat release rate (HRR) is defined as a time-depending function to conform the reference curve experimentally defined by Joyeux et al. [16] which was also used in mentioned studies $[9,10]$. The burning area (red colour in Fig. 2 left) with prescribed HRR can be characterized as a pool fire [17] inside the noncombustible car frame, taking into account all combustible materials inside a car [18-22]. The reference curve is shown in Fig. 2 (right) together with the results of the mesh sensitivity analysis carried out for mesh cell size $100 \mathrm{~mm}, 200 \mathrm{~mm}$ and $300 \mathrm{~mm}$.
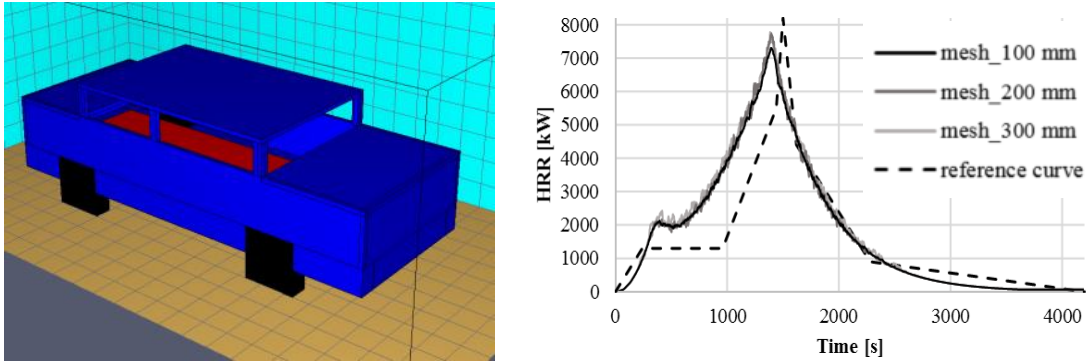

Fig. 2. Geometry of modelled car (left) and mesh sensitivity analysis (right). 
According to the mesh sensitivity analysis results, the mesh sell size $300 \mathrm{~mm}$ is chosen for the modelled scenario. To reduce the simulation time, half of the parking storey area is modelled and is divided into 6 meshes with, overall, 103400 cells. The geometry, material characteristics and boundary conditions are modelled to represent the designed building properties. The proposed fire scenario is simulated with three different venting boundary conditions - as open, semi-open and closed building envelope walls.

The temperatures of the analysed beam are measured with FDS measuring devices (\&DEVC) placed on the cross-section web and flange every $600 \mathrm{~mm}$ along the beam. The measuring quantity of the devices is the adiabatic surface temperature which already takes into account the material heat transfer coefficient and can be used as the input for potential follow-up FEM analysis [23].

The total simulation time of all three scenarios is 60 minutes (3600 seconds). The simulations were computed in FDS version 6.7 .0 on the computing cluster at University of Zilina.

\section{Results}

The following Fig. 3 shows the chosen representative simulation results as temperaturetime curves of the beam section with the highest obtained temperatures (middle) and lowest obtained temperatures (end section towards floor area centre). Plotted curves show the beam flange temperatures for open, semi-open and closed carpark simulation scenarios and the flange temperature if exposed to standard fire curve ISO 834.
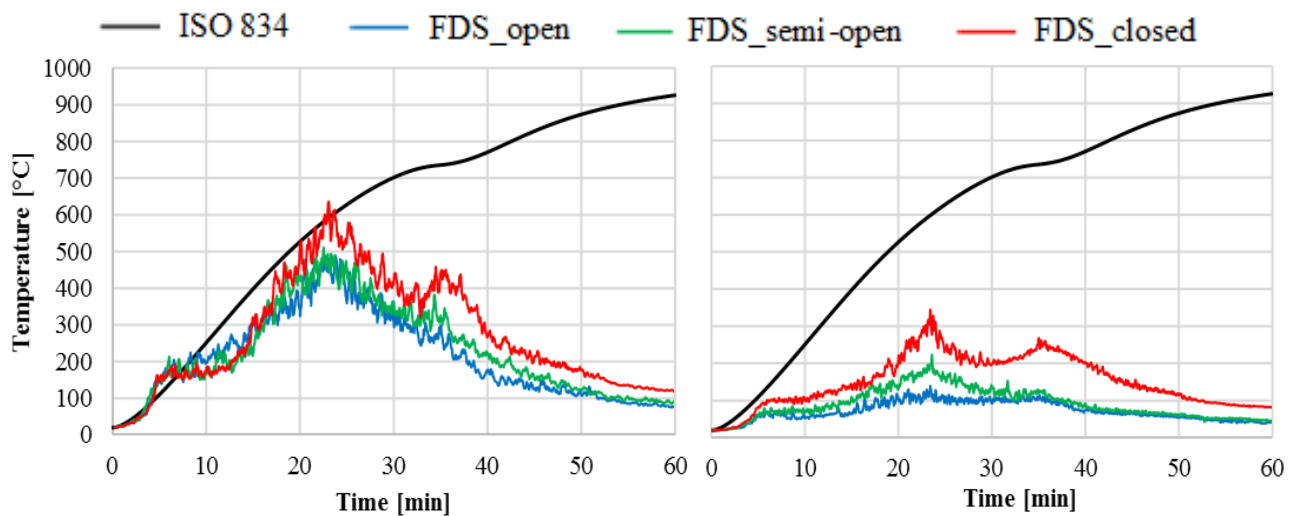

Fig. 3. Obtained steel beam surface temperatures in middle section (left) and end beam section (right).

The results presented in Fig. 3 show that obtained steel temperatures with CFD simulation are lower comparing to the standard curve approach during the fire development phase. The difference is more significant in the end beam section. The CFD output temperatures copy the modelled fire development which consists of the first burning car fire growth, its afterburning phase, fire spread to the two adjacent cars, its fire growth and afterburning phase. On the other hand, the temperature obtained with nominal approach develops according to the standard fire curve and represents only fire growth phase for the whole analysed time.

\section{Conclusions}

The paper is focused on CFD numerical fire modelling in order to obtain input temperature data for advanced structural analysis. Modelled fire scenarios represent fire conditions of overall three adjacent cars in open, semi-open and closed carpark building. The position of 
the burning cars is chosen in order to achieve the highest temperatures (the worst fire scenario) of selected beam. The beam is designed as unprotected steel element with HEB500 cross-section.

The obtained steel temperatures are compared with steel temperatures for the case of the beam exposure to the standard fire curve. The results are presented for the middle beam section, with the highest temperatures, and end beam section, with the lowest temperature values.

In both cases, obtained temperatures are lower than standard approach temperatures during the fire growth. As assumed, at the end section the difference is more significant. During the afterburning phase the difference grows in both sections as standard fire curve (ISO 834) does not take into account the afterburning phase. This verifies the assumption that numerical approach would provide not only more realistic fire development but is also efficient if the unprotected steel structure is designed. The presented results also show temperature differences for individual CFD scenarios. As assumed, the temperature values are lower while the ventilation rate rises. Therefore, the ability of CFD models to represent different boundary conditions is proved.

\section{References}

1. Figuli, L.; Zvaková, Z.; Bedon, C. Design and Analysis of Blast Loaded Windows. Procedia Engineering 2017, 192, 177-182, doi:10.1016/j.proeng.2017.06.031.

2. Bedon, C., Figuli, L. An overview on current methods and trends for enhancing the blast resistance and protection of existing windows. Transport Means - Proceedings of the International Conference Volume 2017-September, 2017, pp 977-984

3. Figuli, L.; Kavicky, V.; Zvaková, Z.; Jangl, Š. Security Zones for Improvised Explosive Devices Using ANFO Explosive; 2016;

4. Erdelyiová, R.; Figuli, L.; Ivančo, M. Prediction of Fire Loading on the Structures Using Computational Fluid Dynamics. MATEC Web Conf. 2020, 313, 00033, doi:10.1051/matecconf/202031300033.

5. EN 1991-1-2: Eurocode 1: Actions Onstructures - Part 1-2: General Actions Actions Onstructures Exposed to Fire 2007.

6. ISO, B. S. 834-11: 2014 Fire Resistance Tests. Elements of Building Construction. Specific Requirements for the Assessment of Fire Protection to Structural Steel Elements. 2014.

7. Nagy, B.; Tóth, E. Finite Element Analysis of Composite Ceramic-Concrete Slab Constructions Exposed to Fire. AMM 2016, 861, 88-95, doi:10.4028/www.scientific.net/AMM.861.88.

8. Performance-Based Design of Structural Steel for Fire Conditions: A Calculation Methodology; Structural Engineering Institute, Parkinson, D.L., Kodur, V., Sullivan, P.D., Eds.; ASCE manuals and reports on engineering practice; American Society of Civil Engineers : Structural Engineering Institute: Reston, Va, 2009; ISBN 978-07844-0963-3.

9. Markert, F.; Guiliani, L. Hydrogen-Fueled Car Fire Spread to Adjacent Vehicles in Car Parks.; Adelaide, Australia, 2019.

10. Heinisuo, M.; Partanen, M. Modeling of Car Fires with Sprinklers. Research Report. 2013, 79.

11. Thaarup, M.; Guiliani, L. Price Optimization of Steel Structures in Car Parks. In Proceedings of the NFSD Nordic Fire \& Safety Days 2019 : Book of abstracts; RISE Research Institutes of Sweden AB, 2019; p. 45.

12. EN 1993-1-2: Eurocode 3: Design of Steelstructures - Part 1-2: General Rules Structural Firedesign 2007. 
13. FDS and Smokeview Available online: https://www.nist.gov/servicesresources/software/fds-and-smokeview (accessed on 11 December 2020).

14. McGrattan, K.B.; Forney, G.P. Fire Dynamics Simulator (Version 4) :: User's Guide; 0 ed.; National Institute of Standards and Technology: Gaithersburg, MD, 2004; p. NIST SP 1019;

15. Márton, T.; Dederichs, A.; Giuliani, L. MODELLING OF FIRE IN AN OPEN CAR PARK. ASFE 2016, doi:10.14311/asfe.2015.060.

16. Demonstration of Real Fire Tests in Car Parks and High Buildings: Final Report; Joyeux, D., Europäische Kommission, Eds.; EUR Technical steel research - steel structures; Off. for Off. Publ. of the Europ. Communities: Luxembourg, 2002; ISBN 978-92-894-4234-3.

17. Marková, I.; Lauko, J.; Makovická Osvaldová, L.; Mózer, V.; Svetlík, J.; Monoši, M.; Orinčák, M. Fire Size of Gasoline Pool Fires. IJERPH 2020, 17, 411, doi:10.3390/ijerph17020411.

18. Osvaldová, L.; Marková, I.; Vandličková, M.; Gašpercová, S.; Titko, M. Fire Characteristics of Upholstery Materials in Seats. International Journal of Environmental Research and Public Health 2020, 17, 3341, doi:10.3390/ijerph17093341.

19. Osvaldová, L.; Gašpercová, S.; Mitrenga, P.; Osvald, A. The Influence of Density of Test Specimens on the Quality Assessment of Retarding Effects of Fire Retardants. 2016, 61, 35-42.

20. Osvaldová, L.; Gašpercová, S. The Evaluation of Flammability Properties Regarding Testing Methods. Civil and Environmental Engineering 2015, 11, doi:10.1515/cee2015-0018.

21. Svetlík, J.; Flachbart, J. The Crew Safety during Burning Car.; 2015; Vol. 2015January, pp. 599-602.

22. Osvaldová, L.M.; Osvald, A. Flame Retardation of Wood. AMR 2013, 690-693, 1331-1334, doi:10.4028/www.scientific.net/AMR.690-693.1331.

23. Wickström, U.; Duthinh, D.; McGrattan, K. Adiabatic Surface Temperature for Calculating Heat Transfer to Fire Exposed Structures. Interflam 2007 2007, 2, 943953. 